\title{
Glycodendritic structures: tools to interact with DC-SIGN
}

\author{
Jose J. Reina, Javier Rojo*
}

Glycosystems Laboratory, Institute of Chemical Research (IIQ), CSIC - Univesity of Seville, Seville, Spain

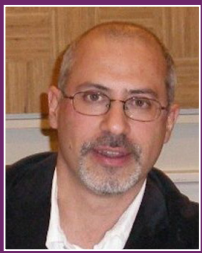

Javier Rojo received a BSc in Organic Chemistry in 1989 , MSc degree in 1990 at the Autónoma University (UAM) Madrid (Spain). Then, he was embarked in the doctoral program to obtain a PhD degree under the supervision of Prof. Juan Carlos Carretero at UAM in 1905 . He was a postdoctoral fellow with Prof. Jean Marie Lehn at the University Jean-Marie Lehn at the University Louis Pasteur in Strasbourg (France) (1995 1998) and with Prof. Larry W. McLaughlin at Boston College in USA (1998-1999). In January 2000, he joined the Carbohydrate Group at the Institute of Chemical Research of (he associate researcher. In 2001 he was awarded a "Ramón y Caja" contract and in 2004 he got a permanent position at the CSIC in Seville as Tenured Scientist. In 2011 he was promoted to Senior Research Scientist. Since April 2012, Javier Rojo is the National Coordinator of Science and Chemical Technology Area of the CSIC. His present research interests are in the field of dendrimers, Cocrat. supramolecular chemistry and carbohydrate molecular recognition. In particular, he is focused on the development of multivalen carbohydrate tools, mainly glycodendrimers, to understand and intervene in those biological processes related with pathogen infection and immunity.

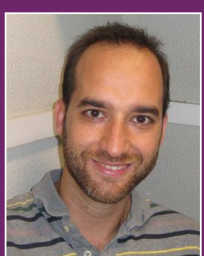

José Juan Reina received a BS in Organic Chemistry in 2001 and a MSc degree in 2003 at the University of Málaga (UMA), Málaga (Spain) Then, he was embarked in the doctoral program to obtain a PhD degree under the supervision of Dr. Javier Rojo at University of Seville - CSIC in 2008. He was a postdoctoral fellow with Prof Anna Bernardi at the University of Milan (Italy) (2009-2012). During this period he was awarded with the prestigious Marie Curie IntraEuropean Fellowship ( Glycosystems Laboratory at the Institute of Chemical Research of the Spanish National Research Council (CSIC) in Seville as a JAE-Doc researcher. His present research interests are in the field of multivalent systems, carbohydrate molecular recognition and design of glycomimetics. In particular, he is focused on the develo development of multivalentcarbohydres mimetics toos to mimic the role of natural oligosaccharides in biological processes related with pathogen infection and immunity.
*Correspondence: Javier Rojo. Glycosystems Laboratory, Instituto de Investigaciones Químicas (IIQ) CSIC, Universidad de Sevilla, Americo Vespucio, 49 - 41092 Sevilla, Spain. E-mail: javier.rojo@iiq.csic.es
The key role of carbohydrates in many biological events has attracted the interest of the scientific community. This fact has demanded the access to new tools necessary to understand this role and the interaction of carbohydrates with their corresponding receptors, lectins. Glycodendrimers and glycodendritic structures in general, have demonstrated to be very efficient and interesting tools to intervene in those processes where carbohydrates participate. In this review, we discuss the different glycodendritic structures that have been used to interfere with DC-SIGN, a very attractive lectin involved in infection processes and in the regulation of the immune response.

Uniterms: DC-SIGN. Ebola. Glycodendrimers. Glycofullerenes. HIV. Mannose.

O papel chave dos carboidratos em muitos eventos biológicos tem atraído interesse da comunidade científica. Este fato demonstrou o acesso de novas ferramentas para a compreensão da interação dos carboidratos com seus receptores correspondentes, lectinas. Glicodendrímeros e estruturas glicodendríticas, em geral, mostram-se como ferramentas muito eficientes e interessantes para intervir nos processos em que os carboidratos participam. Nesta revisão, discutimos diferentes estruturas glicodendríticas que têm sido úteis para interferir com DC-SIGN, uma lectina muito atraente envolvida em processos infecciosos e na regulação da resposta imune.

Unitermos: DC-SIGN. Ebola. Glicodendrímeros. Glicofulerenos. HIV. Manose.

\section{INTRODUCTION}

Glycans are not only an important source of metabolic energy; they are also widely expressed as glycoconjugates on the surface of cells where they play a key role in many important biological processes (Varki, 1993; Kamerling 2007; Werz, Seeberger, 2007). In the past decade, the increased appreciation for the ubiquity of glycans and their ability to encode biochemical information has given rise to the field of glycobiology (Varki, 1999; Bertozzi, Kiessling, 2001) with the aim to explain and understand how chemical information is encode in sugar structures and how this information is read out by sugar binding proteins (lectins) (Gabius et al., 2011; Gupta, Surolia, 2012). Lectins are proteins that recognize glycans (glycolipids and glycoproteins) with high specificity, and this carbohydrate-lectin interaction is implicated in several important biological events such as cell-cell self-recognition processes, cell-extracellular matrix interaction, gamete fertilization, embryonic development, cell growth, cell differentiation, cell signaling, cell adhesion and migration, apoptosis, immuno- 
modulation and inflammation, host-pathogen interactions, glycoprotein folding and routing, mitogenic induction and homeostasis (Varki, 1993; Weis, 1998; Sharon, Lis, 2004; Ghazarian, 2011). Thus, in principle, lectins can clearly be considered as potential targets for the development of new drugs. However, they have rarely been exploited for the discovery of novel therapeutic opportunities. Frequently, medicinal chemists have mostly disregarded carbohydrates as a class of molecules for drug development, basically due to their poor drug-like properties including their low stability and their high polar character.

Carbohydrate-protein (carbohydrate-lectin) interactions are characterized by a high selectivity, metal ion dependence, and a low affinity compensated in nature by a multivalent presentation of glycans and receptors (Lee, Lee, 1995; Chabre, Roy, 2010). The carbohydrate recognition domains (CRD) of lectins are often able to recognize complex oligosaccharides in a selective manner; however, the recognized oligosaccharide determinants often consist of only one or two residues, usually located in the nonreducing end of the oligosaccharide structure, that appear to act as anchors, driving the entire glycoconjugate to interact with the protein. The most abundant animal lectins are the C-type lectins (CTL) (Kilpatrick, 2000), that in most of the cases are large, asymmetric trans-membrane glycoproteins, with one or more CRDs attached to a variable number of structurally and functionally different polypeptide domains.

The interaction between sugars and lectins is driven by hydrogen bonds, coordination of monosaccharide residues with metals (for C-type lectins and related calciumdependent proteins), ionic and hydrophobic interactions, that all contribute to the binding affinity (Weiss, Drickamer, 1996). The energy associated with hydrogen bonding in sugar-protein interactions is significantly reduced by competition from bulk solvent and by the flexible nature of hydroxyl groups, which results in a considerable entropic penalty when they become constrained upon binding. Sugar $\mathrm{CH}$ bonds can engage in stacking interactions with protein aromatic side chains, but natural carbohydrates usually lack extended hydrophobic areas, often a dominant factor in high-affinity receptor-ligand interactions. Hence, the affinity of lectins for monovalent carbohydrates is typically weak (dissociation constants are in the $\mathrm{mM}$ to $\mu \mathrm{M}$ range). However, most lectins are multimeric and, therefore, polyvalent presentations of monosaccharides acting as binding determinants for a given lectin can be used for inhibition, increasing the affinity in comparison with the corresponding monovalent ligands (Mammen, 1998; Culf, 2006; Turnbull, Field, 2007). For this aim, a vast array of unnatural glycoconjugates (neoglycoconju- gates) with different valencies and spatial arrangement of the ligand have been constructed as sugar binding proteins antagonist to prevent or treat diseases caused by pathogens (Bernardi et al., 2013). Scaffolds based on peptides and proteins (Davis, 2002; Payne, Wong, 2010; Westerlind, 2012), polymers (Miura, 2012; Eissa, Cameron, 2013), calixarenes (Baldini, et al., 2007; Dondoni, Marra, 2010), dendrimers (Li, Cheng, Xu, 2007; Chabre, Roy, 2008), cyclodextrins (Fulton, Stoddart, 2001; Gomez-Garcia, 2012; Martínez, Ortíz Mellet, García Fernández, 2013), cyclopeptides (Galan, Dumy, Renaudet, 2013), fullerenes (Nierengarten, 2010), gold nanoparticles and quantum dots (El-Boubbou, 2011; Marradi et al., 2013) provide nanoscale materials with anti-adhesive and cell targeting properties.

In our research group, we are interested in a specific lectin named DC-SIGN, a C-type lectin able to recognize and interact with a number of highly glycosylated proteins presented in the surface of a diverse group of pathogens (Van Kooyk, Geijtenbeek, 2003). The broad pathogen spectrum that could use DC-SIGN during the infection process places this lectin as an important target in infection diseases. In the present review, we will describe the approaches to design and synthesize glycodendritic antagonist for DC-SIGN.

\section{DC-SIGN}

DC-SIGN (Dendritic cell-specific ICAM-3 grabbing nonintegrin, CD209) was originally defined as an intercellular adhesion molecule-3 (ICAM-3) receptor that play an important role in establishing the first contacts between dendritic cells (DCs) and resting T cells (Geijtenbeek et al., 2000). It is a type II trans-membrane C-type lectin with a single C-terminal Carbohydrate Recognition Domain (CRD). In the cellular membrane, DC-SIGN is assembled as a tetramer, due to an extended coiled-coil region that allows simultaneous presentation of four CRDs (Mitchell et al., 2001; Feinberg et al., 2005; Serrano-Sierra-Gomez et al., 2008; Tabarani et al., 2009).

DC-SIGN is one of the dendritic cells specific pathogen-uptake receptors and recognizes glycoconjugates on the surface of several pathogens, including viruses (HIV, Ebola, Cytomegalovirus, Dengue, SARS), bacteria (M.tuberculosis, S. pneumoniae), fungi (C. albicans, A. fumigatus), and parasites (Leishmania, S. mansoni) (Van Kooyk, Geijtenbeek, 2003). It has been proven that this lectin plays a key role in the initial steps of infections caused by some of these pathogens. In particular, DC-SIGN was brought to attention by the group of van Kooyk, who reported that HIV-1 targets DC-SIGN, but escapes degradation in lytic 
compartments, thus using DCs as a Trojan horse to invade the host organism (Geijtenbeek et al., 2000a). Inhibition of DC-SIGN is currently considered as an interesting approach for the design of new anti-infective agents (Reina et al., 2010; Sánchez-Navarro, Rojo, 2010; Reina, Bernardi, 2012). The detailed molecular mechanism by which this receptor operates is not fully understood, thus effective modulators of DC-SIGN are also needed to unravel the different biological processes in which this receptor is involved. The main carbohydrate ligand recognized by DC-SIGN is the high mannose glycan, (Man $)_{9}(\mathrm{GlcNAc})_{2}$, (Figure 1) a branched oligosaccharide presented in multiple copies by several pathogen glycoproteins and specifically by the gp 120 envelope protein of HIV. DC-SIGN can also recognize branched fucosylated structures bearing terminal fucose residues, such as the Lewis antigens.

The primary interaction of oligosaccharides and DC-SIGN occurs by coordination of a residue of the oligosaccharide (often the non-reducing end) to a $\mathrm{Ca}^{2+}$ binding site exposed to the surface of the protein (Feinberg et al., 2001; Guo et al., 2004; Feinberg et al., 2007). X-ray data are available for complexes of the DC-SIGN carbohydrate recognition domain (CRD) with both mannose oligosaccharides and Lewis-X (Feinberg et al., 2001; Guo et al., 2004; Feinberg et al., 2007). Besides the role that DCSIGN plays in infection processes, the recent discovery of DC-SIGN as a lectin involved in immunoregulation processes attracted the interest of many scientists due to the possibility to exploit this lectin as a new potential target in immunotherapy. This important discovery has opened the possibility to design specific carbohydrate multivalent systems to modulate the immune response through the interaction with DC-SIGN. This is a field of tremendous interest and very active research is ongoing in this area for the design of new glycodendritic structures targeting this receptor.

\section{CARBOHYDRATES MULTIVALENT COM- POUNDS TARGETING DC-SIGN}

Highly mannosylated polyvalent compounds have been developed in an effort to target DC-SIGN mediated viral transmission. This topic has been recently reviewed (Sánchez-Navarro, Rojo, 2010) and therefore, only two representative examples, one based on gold nanoparticles and another one based on a polymer scaffold have been selected to be highlighted in the present review.

Penadés and Alcami have reported a remarkable example using gold nanoparticles (GNP) displaying different mannosyl oligosaccharides (Manno-GNPs) as potent inhibitors of DC-SIGN mediated HIV trans-infection of human activated peripheral blood mono-nuclear cells (Martinez-Avila et al., 2009). The selected ligands were linear and branched oligosaccharides containing one to seven mannose units. Using Biosensors with Surface Plasmon Resonance (SPR) detection it was demonstrated that these GNPs were very good inhibitors in a competitive study using DC-SIGN and gp120 (Hijazi, 2009). In particular, the GNPs functionalized with the linear disaccharide Manalpha1-2Man was the best inhibitor showed a
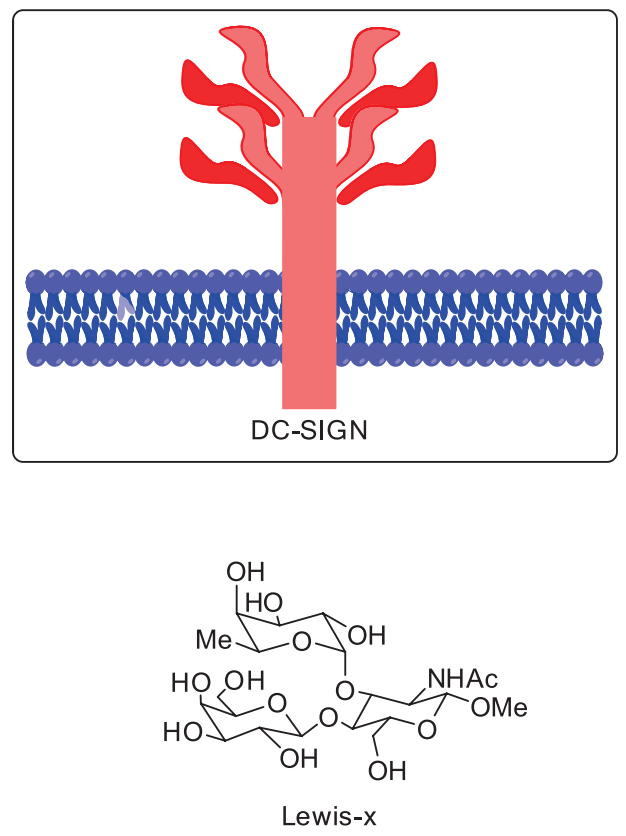

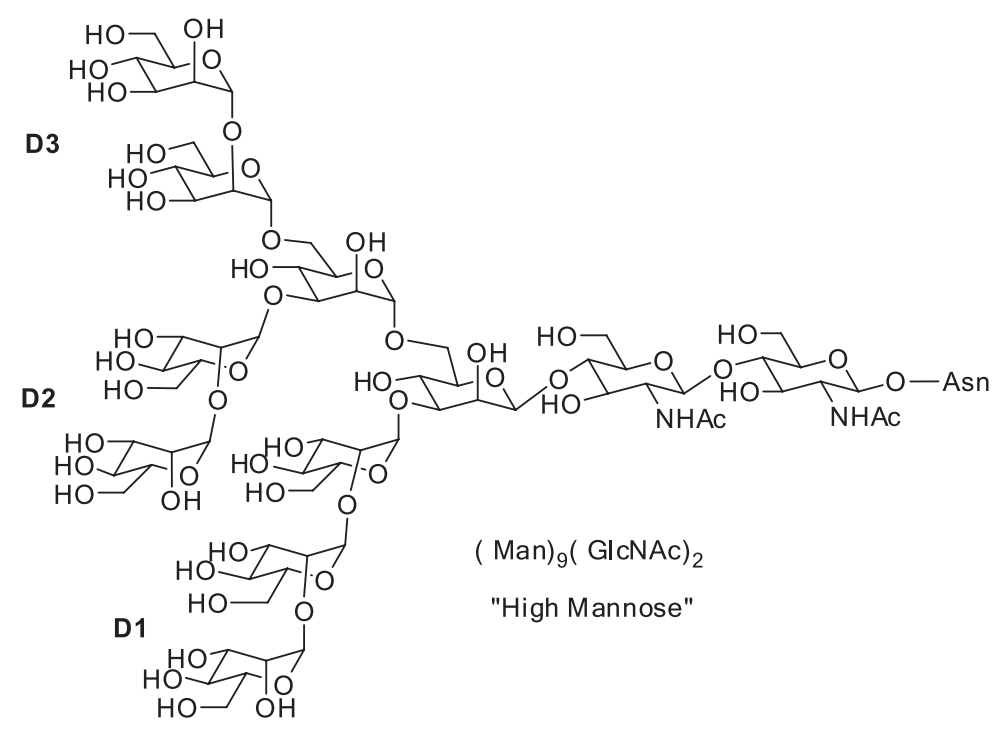

FIGURE 1 - Cartoon of DC-SIGN and chemical structure of Lewis X and (Man $)_{9}(\text { GlcNAc) })_{2}$ glycans. 
20,000-fold increased activity in comparison with the corresponding monovalent ligand. It was also demonstrated that the maximum activity was achieved with $50 \%$ surface density. A selection of GNPs was tested in in vitro HIV-1 infection studies using viruses with different tropism (Martinez-Avila et al., 2009). The experiments demonstrated that these GNPs were able to inhibit the trans-infection of $\mathrm{T}$ cells at very low concentrations. In particular, the GNP with 56 copies of a linear tetrasaccharide at a density of $50 \%$ (Figure 2) was the most potent inhibitor with an $\mathrm{IC}_{50}$ in the low nanomolar range. This is the first example where a carbohydrate multivalent system has been tested in in vitro HIV infection studies successfully.

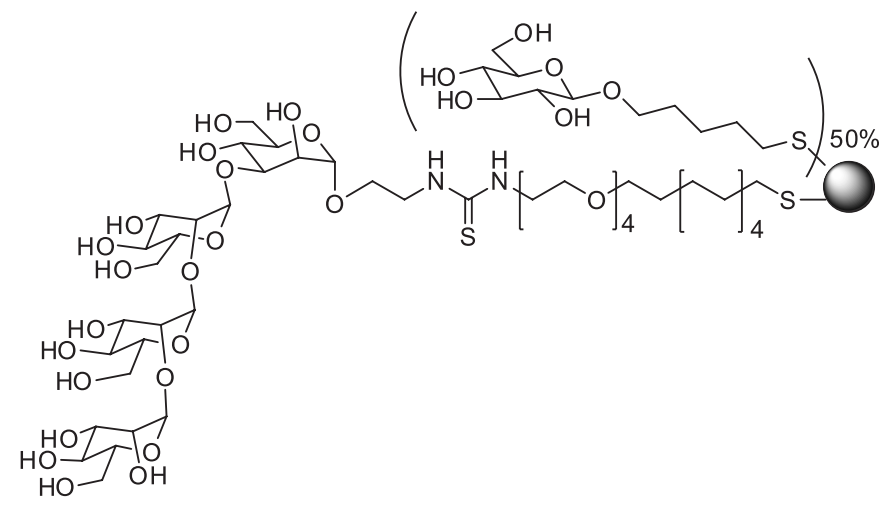

FIGURE 2 - Gold glyconanoparticle with $50 \%$ of glucose and $50 \%$ of a linear tetrasaccharide.

Another approach to prepare DC-SIGN inhibitors was described by the group of Kiessling, who used a shikimic acid-derived glycomimetic scaffold of general formula A (Schuster et al., 2003; Gaber et al., 2010). (Figure 3). The shikimic acid derivative prepared by Kiessling and co-workers shared the same hydroxyl arrangement as mannose at positions 2, 3 and 4, and could be considered as a good mimetic of mannose for lectin recognition. In addition to the hydroxyl groups that mimic mannose, this shikimic acid derivative presented two possible points of diversification, a carboxylic group and a thiol that were exploited to introduce different substituents and to synthesize a library of 192 compounds. All these compounds were tested using a fluorescence-based high-throughput competition assay that assessed their ability to compete with immobilized mannan for binding the fluorophorelabeled extracellular domain of DC-SIGN. The best compound of the library was B, (Figure 3 ) which had an $\mathrm{IC}_{50}$ of $11.2 \mathrm{mM}$, but was found to be more selective for DC-SIGN than for mannose-binding protein A (MBP-A). A multivalent presentation of compound $\mathbf{B}$ was prepared by ring-opening metathesis polymerization (ROMP) (Bielawski, Grubbs, 2007). The final glycopolymer was 1000 -fold more potent than the monomeric inhibitor, the compound $\mathbf{B}$.

\section{GLYCODENDRIMERS TARGETING DC-SIGN}

There are several precedents where dendrimers have been used as scaffolds to achieve a multivalent presentation of carbohydrates, the so called glycodendrimers. Furthemore, it have been observed that these kind of

\section{Gerenal formula of the library}<smiles>[R5]S[SH][C@@H]1[C@H](C(=O)NC([R])C(N)=O)C[C@H](O)[C@@H](O)[C@@H]1O</smiles>

A

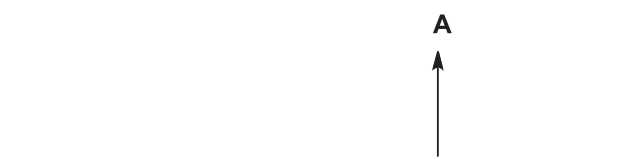

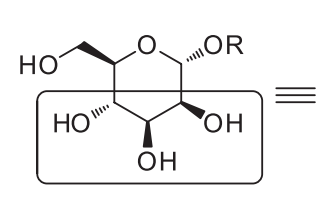

$\alpha$-mannose

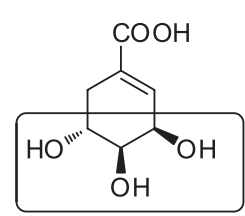

Shikimic Acid
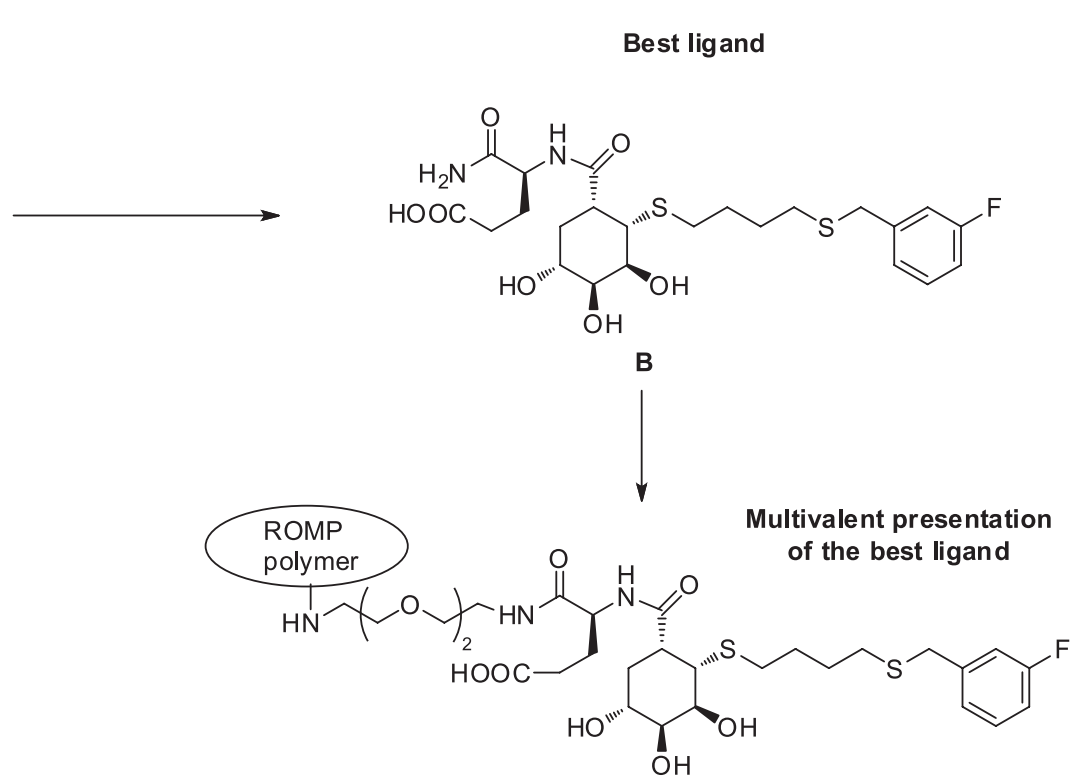

same cofiguration of the hydroxyl groups

FIGURE 3 - Shikimic-based derivatives as ligands for DC-SIGN. 
carbohydrates multivalent systems are important tools to interfere in biological processes where lectins or sugar binding proteins are implicated (Roy, 1996; Turnbull, Stoddart, 2002; von der Lieth, Frank, Lindhorst, 2002; Roy, Baek, 2002; Bezouška, 2002; Roy, 2003; Li, Cheng, Xu, 2007; Chabre, Roy, 2008, 2010; Sánchez-Navarro, Rojo, 2010).

Among them, a recent interesting example where a glycodendron was used to interact with DC-SIGN was described by Wong and co-workers. They have reported oligomannose dendrons which display 3, 9 and 27 copies of complex oligomannoses (Figure 4) in high density as inhibitors of gp 120 binding to recombinant dimeric DC-SIGN (Wang et al., 2008). The selected carbohydrates were a linear tetramannosyl ligand $\left(\mathrm{Man}_{4}\right)$ corresponding to the D1 arm of high mannose and a branched nanomannosyl oligosaccharide that represented the high mannose glycan (Figure 1). In a competition experiment using gp120 as a ligand for DC-SIGN, it was demonstrated that these glycodendrons inhibited the binding between gp120 and DC-SIGN with an $\mathrm{IC}_{50}$ of 20 and $8 \mathrm{nM}$ for compounds with nine copies of $\mathrm{Man}_{4}$ and nine copies of $\mathrm{Man}_{9}$, respectively.

Since almost a decade ago, our group is interested in the design and synthesis of different multivalent compounds based on mannose and glycomimetics of high mannose oligosaccharides and Lewis-X, as potential molecules able to block the binding of pathogen envelope glycoproteins to DC-SIGN. For this aim, we focused on dendrimers and dendritic structures as appropriate scaf- folds for a multivalent presentation of carbohydrates trying to achieve binding affinities to DC-SIGN in the $\mu \mathrm{M}$ to $\mathrm{nM}$ range, a task without precedents at that time. In this revision article, we will give and overview of the work performed in our group related with glycodendritic structures as DC-SIGN antagonist.

\section{Boltorn-type glycodendritic structures}

As a proof of concept, we addressed a divergent approach (Fréchet, Tomalia, 2001; Newkome, Moorefield, Vögtle, 2001; Sánchez-Navarro, Rojo, 2012) to synthesize glycodendrimers using very simple and accessible molecules. We selected a Boltorn hyperbranched dendritic polymer, commercially available at a very low price, as scaffold and a simple monosaccharide, mannose, as ligand to DC-SIGN to be conjugated on it. These hyperbranched polymers have been constructed using bis-hydroxymethylpropionic acid (Bis-MPA) as building block and pentaerythritol as core. The glycodendritic polymers were prepared using the $2^{\text {nd }}$ and $3^{\text {rd }}$ generation of Boltorn dendritic polymers conjugated with 16 and 32 mannoses, respectively. (Figure 5). We demonstrated that these glycodendritic structures were perfectly soluble in physiological conditions, non-toxic against several cell lines and easy to be prepared (Arce et al., 2003).

The affinity of these glycodendritic polymers to DCSIGN was evaluated using a SPR biosensor (Tabarani et al., 2006). Experiments clearly shown that the binding of

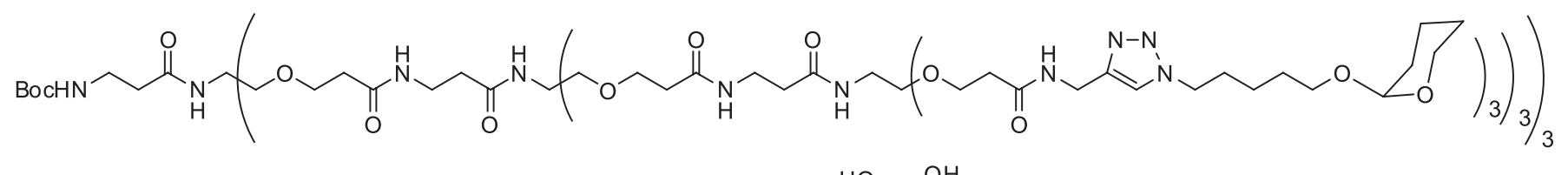
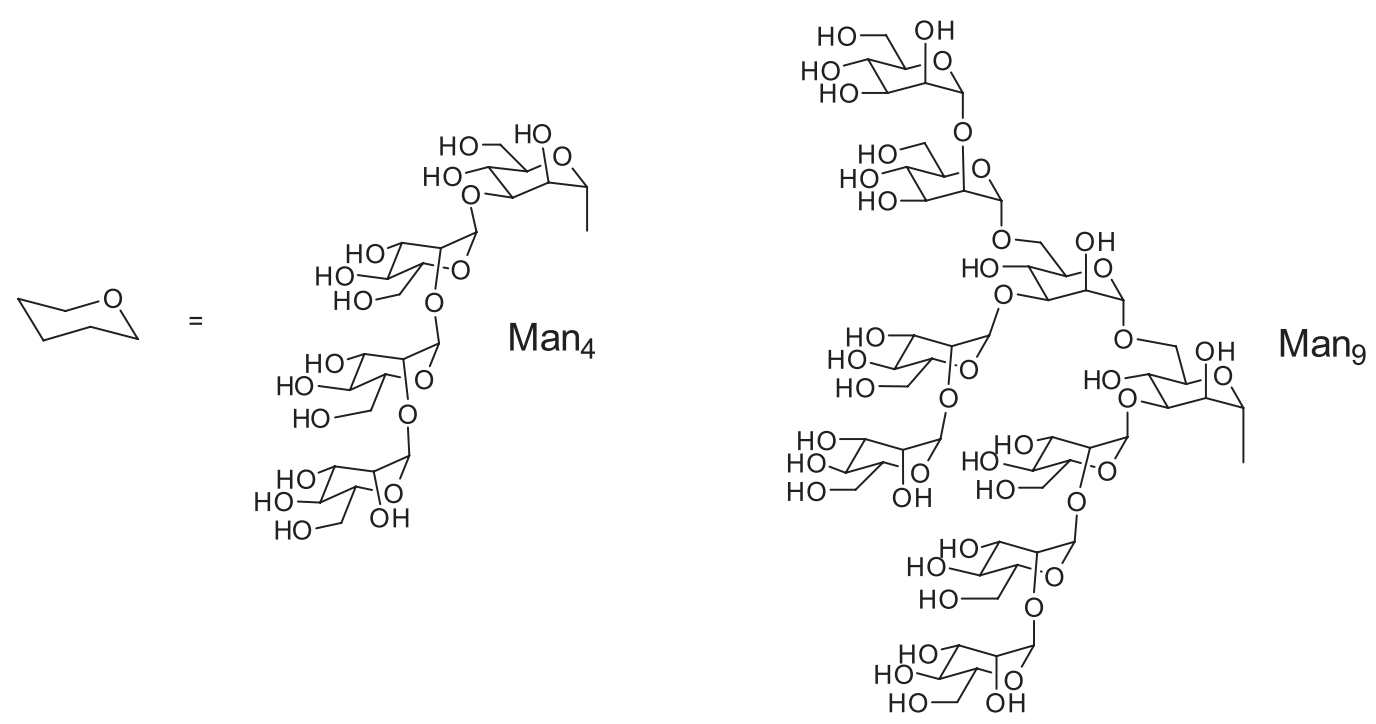

FIGURE 4 - Glycodendrons with 27 copies of $\mathrm{Man}_{4}$ and $\mathrm{Man}_{9}$. 


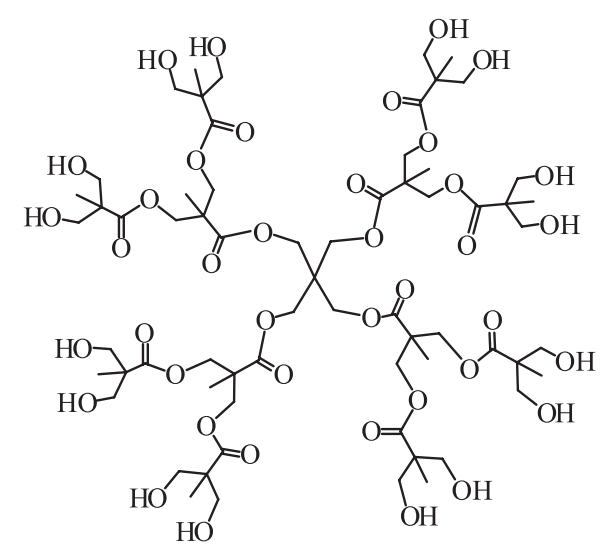

$\mathrm{BH} 20$

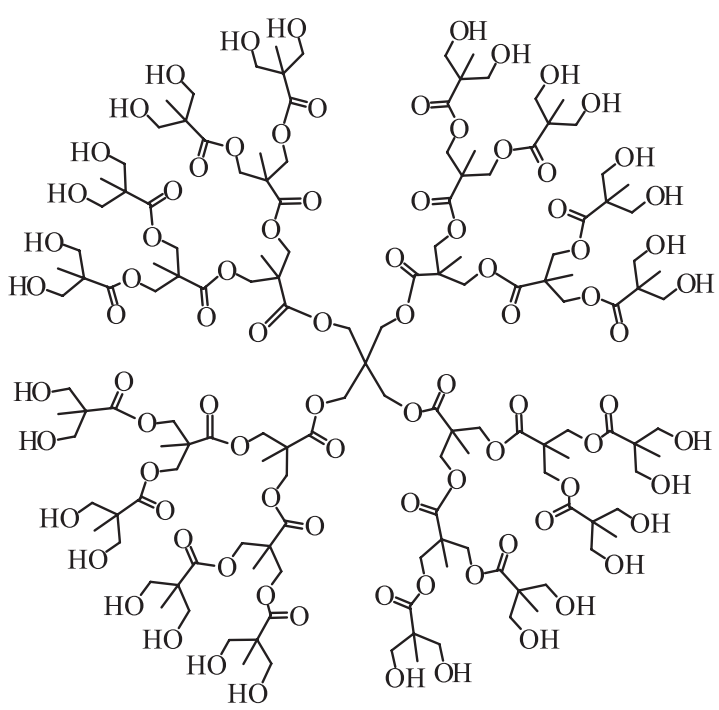

$\mathrm{BH} 30$

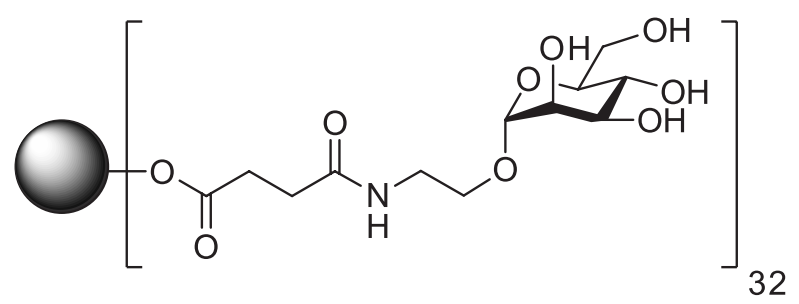

BH30sucMan

FIGURE 5 - Boltorn hyperbranched structures of $2^{\text {nd }}(\mathrm{BH} 20)$ and $3^{\text {rd }}(\mathrm{BH} 30)$ generation and the glycodendrimer BH30sucMan.

BH30sucMan based on BH30 ( $3^{\text {rd }}$ generation of Boltorn) to DC-SIGN was calcium and carbohydrate dependent and therefore should take place through the carbohydrate recognition domain of the lectin. An apparent affinity in the sub microMolar range was found ( 3 orders of magnitude increase in comparison with the monovalent mannose). Using SPR, we also set up a competition experiment assay in which different glycodendritic structures were analyzed for their ability to inhibit the gp120/DC-SIGN interaction, finding an $\mathrm{IC}_{50}$ of $50 \mu \mathrm{M}$ for BH30sucMan. Additionally, it was demonstrated the antiviral properties of the mannosyl glycodendritic structure BH30sucMan using an Ebola Virus infection model. This glycodendritic hyperbranched polymer inhibited DC-SIGN-mediated Ebola Virus infection in cis and in trans (Lasala et al., 2003; Rojo, Delgado, 2004). The experiment showed that BH30sucMan was able to selectively inhibit direct DC-SIGN-mediated Ebola infection in an efficient dose-dependent manner $\left(\mathrm{IC}_{50} 337\right.$ $\mathrm{nM})$. In the experiment in trans, in which a more complex series of events such as internalization and presentation of the viral particle to susceptible cells can take place, BH30sucMan also showed a significant reduction of DC-
SIGN-mediated infection in trans at levels comparable to the inhibition shown in cis. These glycodendritic polymers were the first example of a multivalent DC-SIGN antagonist describe in the literature.

After this proof of concept where sub micromolar apparent affinity and good antiviral activity have been reached presenting a simple carbohydrate (a mannose monosaccharide) as ligand for DC-SIGN, an improvement of these activities could be envisaged using more complex and specific carbohydrate ligands. Moreover, Boltorn hyperbranched dendritic polymers are polydisperse materials and the control of the synthesis and the reproducibility of biological assays could be compromised by the presence of a mixture of compounds. A monodisperse Boltorn type dendrimers and dendrons were prepared using a step-wise synthesis avoiding these potential problems. In this way, a new set of carbohydrate multivalent compounds were synthesized using these monodisperse multivalent scaffolds.

From the point of view of the ligand moiety, it has been reported the design and synthesis of two glycomimetic compounds that bind to DC-SIGN. A pseudo-1,2mannobioside 1 (Figure 6), which contains a mannose unit 
connected to a conformationally locked cyclohexanediol to mimic 1,2-mannobioside (Man $\alpha(1,2)$ Man) (Reina et al., 2007). The pseudo-trisaccharide 2 mimicking the linear Man $\alpha(1,2)$ Man $\alpha(1,6)$ Man trisaccharide of the D3 arm of $\mathrm{Man}_{9}$, (Figure 6) was designed following the same concept (Mari et al., 2007). The affinity for DC-SIGN of both monovalent ligands was too weak ( $\mathrm{mM}$ range) to be considered as effective inhibitors of DC-SIGN-mediated infections and their therapeutic potential was limited. However, this low affinity could be overcome when ligands were presented in a multimeric form.

The multivalent presentation of glycomimetics 1 and 2 was achieved by conjugation of the monovalent ligands to tetra- and multivalent scaffolds based on Bis-
1
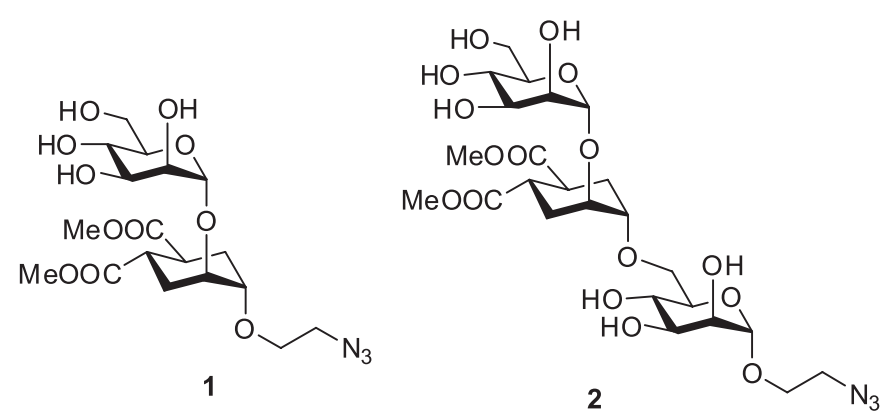

FIGURE 6 - pseudo-disaccharide 1 and pseudo-trisaccharide 2.
MPA as building block to generate dendritic compounds with Boltorn-type structures. Two scaffolds with different valency were synthesized: a tetravalent dendron and a $3^{\text {rd }}$ generation Boltorn-type dendrimer, both being monodisperse compounds. The corresponding tetravalent glycodendrons 3 and 4, and the multivalent glycodendrimers 5 and 6 (Figure 7) were evaluated as potential inhibitors of DC-SIGN (Sattin et al., 2010).

The tetravalent dendron 4 with four copies of pseudo-trisaccharide 2 was shown to inhibit the trans infection of T lymphocytes by HIV. Infection was abrogated almost totally by 4 at $100 \mu \mathrm{M}$ concentration, and an $\mathrm{IC}_{50}$ ca. $10 \mu \mathrm{M}$ could be estimated (Sattin et al., 2010), a very promising value as starting point to define better antiviral compounds. Furthermore, dendron $\mathbf{4}$ was evaluated as a suitable candidate for the development as topical HIV microbicide (Berzi et al., 2012). This compound was tested as inhibitor in an experimental model based on HIV infection of explant tissues taken from human uterine cervix. This experiment was the previous step to test the inhibitors in in vivo models. It was demonstrated that dendron 4 inhibited $80-90 \%$ of cervical explant HIV infection.

Additionally, the tetra- and multivalent systems were tested in vitro using an infection model based on pseudotyped viral particles with the Ebola virus envelope glycoprotein GP1. In these experiments, the tetravalent

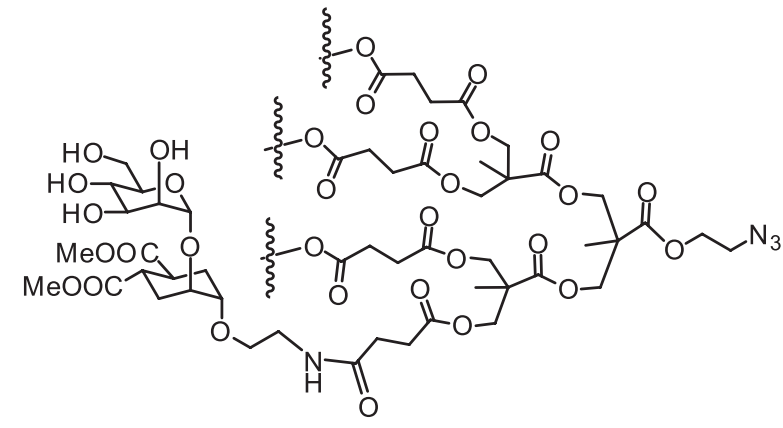

3

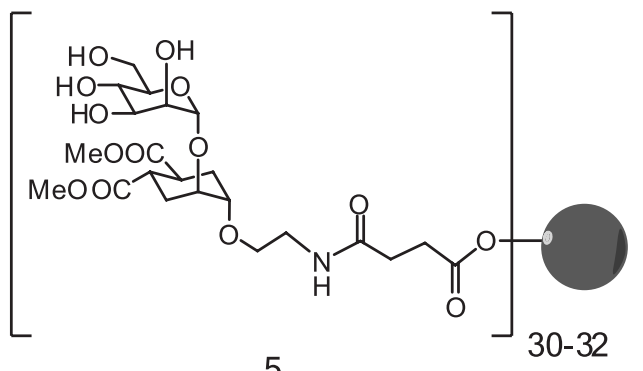

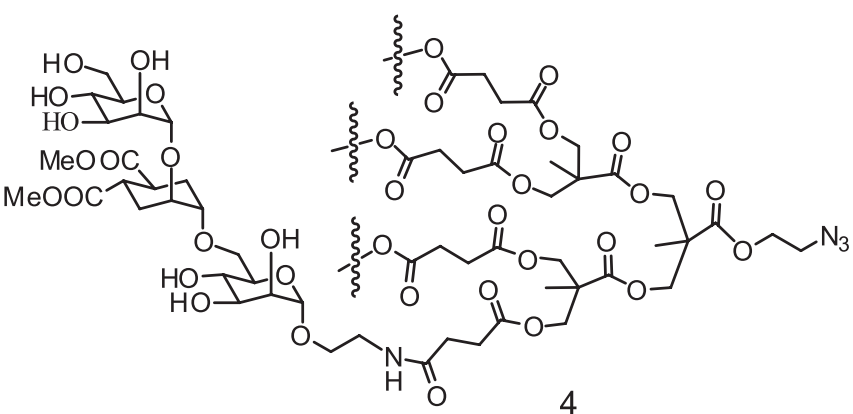

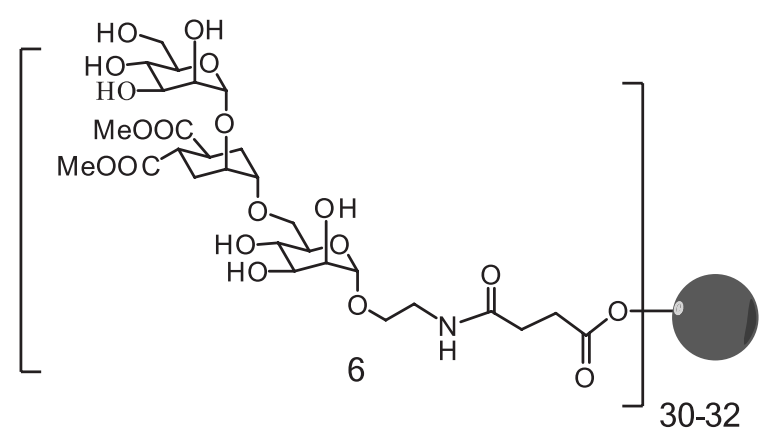

FIGURE 7 - Structure of tetravalent glycodendrons $\mathbf{3}$ and $\mathbf{4}$ and glycodendrimers $\mathbf{5}$ and $\mathbf{6}$. 
systems 3 and $\mathbf{4}$ were very active in the low micromolar range, and the multivalent systems $\mathbf{5}$ and $\mathbf{6}$ showed a very strong inhibition effect with $\mathrm{IC}_{50}$ in the nanomolar range (Luczkowiak et al., 2011).

\section{Glycodendritic systems based on the $\mathrm{Cu}$ (I) catalyzed azide-alkyne cycloaddition (CuAAC)}

In the previous section, it has been described an approach to create carbohydrates multivalent systems based on Boltorn type structures. The synthesis of these kinds of polyesters-based glycodendrons and glycodendrimers presented some disadvantages. The divergent synthetic approach entailed the attachment of the saccharidic units to the multivalent scaffold in the last stage, generating several covalent bonds simultaneously in a single synthetic step. For this reason, this approach can generate structural defects due to an incomplete conjugation giving rise to molecules with similar structure, and physical and chemical properties and therefore, being very difficult the purification step to get pure and monodisperse glycodendrimers. A more efficient strategy should be addressed to achieve the preparation of this kind of molecules.

In this context, our group designed new multivalent systems based on a convergent strategy using a very efficient type of click reaction (Kolb, Finn, Sharples, 2001), in particular, the $\mathrm{Cu}$ (I) catalyzed azide-alkyne cycloaddition (CuAAC) (Rostovtsev et al., 2002; Tornøe, Christensen, Medal, 2002), as an alternative to the preparation of glycodendrons and glycodendrimer. The click chemistry reaction $\mathrm{CuAAC}$ is a very efficient, versatile, and popular reaction that has found several applications in many fields to achieve the preparation of very diverse molecules ranging from small compounds to polymers, hydrogel and other larges entities, including dendrimers (Wu et al., 2004; Joralemon et al., 2005; Malkoch et al., 2005; Fernández-Megia et al., 2006; Franc, Kakkar, 2010). Following a convergent strategy based on CuAAC reaction, the synthesis of a new class of glycodendrons with full control of the structure was developed. In the new design, it was considered the presence at the focal position of an appropriated functional group permitting the conjugation of biomolecules of interest (peptides, nucleic acids, etc.) using again a $\mathrm{CuAAC}$ reaction. Glycodendrons, containing up to nine copies of carbohydrate ligands (mannose or fucose) (Figure 8), showed an efficient binding with the DC-SIGN receptor at the surface of DCs (Ribeiro-Viana et $a l ., 2012)$. The functional group at the focal position was used to conjugate a fluorophore (a BODIPY derivative) to study the DC-SIGN-mediated internalization of these glycodendrons after the binding event at the surface of DCs.
These glycodendrons internalized efficiently into monocyte derived DCs in a receptor-dependent manner as it was demonstrated using imaging flow cytometry. Additional experiments performed to determine the intercellular routing of these molecules into DCs showed that glycodendrons were co-localized within lysosomes. Finally, it was evaluated the capacity of glycodendrons to induce the maturation of DCs. None of the glycodendron showed any activity to induce DCs maturation neither expression of cytokines at the concentration tested. Besides this fact, they can be considered as interesting vectors to internalize into target cells biomolecules of interest such as immunogenic peptides, conjugated to the focal position of these glycodendrons, opening the door for their use to develop synthetic vaccines.

This convergent click chemistry approach to prepare glycodendritic structures could be applied to different scaffolds generating interesting carbohydrate multivalent systems.

\section{Glycodendrofullerenes}

Fullerene could be a very attractive core with a rigid spherical shape for a unique globular carbohydrate multivalent presentation. However, its low solubility in polar solvents is one of the major drawbacks to address the preparation of biological active compounds. On the other hand, fullerenes allow the possibility to functionalize its 3D structure in different positions of the C60 cage in a controlled fashion. Initially, the approaches reported in the literature to synthesize fullerenes derivatives bearing carbohydrates were based on a mono-addition pattern (Nishida et al., 2004; Enes et al. 2005) on the fullerene sphere or on a "one side" multi-addition pattern (Cardullo et al., 1998; Ito et al., 2003; Kato et al., 2005; Isobe et al., 2007). In all these cases, fullerene derivatives showed an amphiphilic character with the fullerene being the lipophilic part of the structures. Recently, it has been shown that this amphiphilic character of sugar fullerene conjugates can be avoided by obtaining hexakis-adducts of [60]fullerene in which the C60 sphere could be completely surrounded by the sugar moieties (mannose, glucose, galactose or fucose) in a $T$-symmetrical octahedral addition pattern (Nierengarten et al., 2010). The conjugation of sugar residues to an alkyne-substituted Bingel-Hirsch hexakis-adducts was performed by employing the $\mathrm{CuACC}$ methodology. So, it was obtained the first example of a globular polytopic ligand named glycofulleres or "sugar balls" (Figure 9).

To increase the valency of these systems, a divalent dendron with mannose was used to obtain the first glycodendrofullerene with 24 sugars moieties on the periphery 


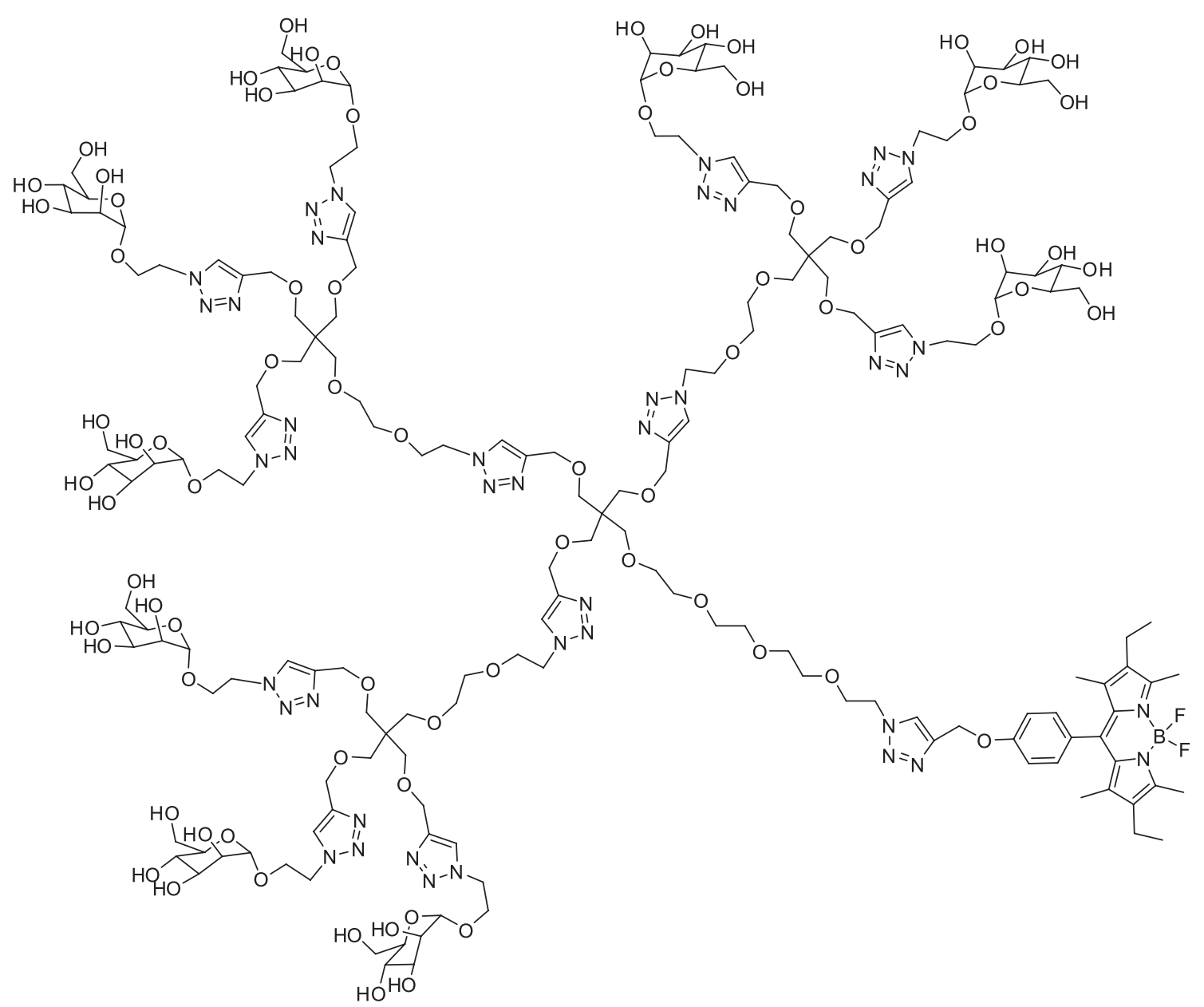

FIGURE 8 - Mannosyl nonavalent dendron fluorescence labeled with BODIPY.

of C60 (Sánchez-Navarro et al., 2011) (Figure 9). These compounds were water soluble and interact with Concanavalin A in a multivalent manner demonstrating the accessibility of the sugars on the fullerene surface to be recognized by a lectin. Moreover, the compounds showed a good stability and low toxicity which confirmed the appropriate features to be used in cellular assays.

Globular glycofullerenes with higher valency were prepared by a convergent strategy combining trimannosylated glycodendrons with a Bingel-Hirsch hexakis-adduct [60]fullerene to obtain glycodendrofullerenes with 36 mannoses (Figure 9) and two different spacers. Also, it was introduced for the first time the biological activity of these compounds in a cellular infection model providing important information about the potential use of these new glycomimetics as viral inhibitors. These glycodendrofullerenes act as antiviral agents in a DC-SIGN dependent Ebola pseudotype infection model (Luczkowiak et al., 2013). Glycofullerene with 12 mannoses showed an $\mathrm{IC}_{50}$ of $2 \mu \mathrm{M}$, a very promising data; however, an unexpected result was obtained for the activity of the glycodendrofullerene with
36 mannoses. The increase of valency induced a loss of antiviral effect $\left(\mathrm{IC}_{50}\right.$ c.a. $\left.70 \mu \mathrm{M}\right)$. This could be probably related to the steric congestion of sugars at the surface of fullerene. Furthermore, one important factor to achieve high affinity in binding processes was not only the spatial presentation of ligands but also the adequate accessibility of these ligands to interact with the receptor, DC-SIGN in this case. Using a glycodendrofullerene with 32 mannose (same valency) but including a longer spacer, was observed a remarkably increase of the inhibitory activity of this compound ( $\mathrm{IC}_{50} 0.3 \mu \mathrm{M}$ ), probably due to a more efficient interaction of the mannose ligand with DC-SIGN. This result highlights the importance to combine an adequate scaffold to achieve the multivalency (the spherical fullerene) with the right ligand accessibility and flexibility. The valency of the compound is an important factor to obtain good affinities in a carbohydrate-lectin interaction but as it has been shown in these assays, it is not the only factor to be taken into account. Based on these results, fullerenes appear as very attractive scaffolds for a globular multivalent presentation of sugars. 

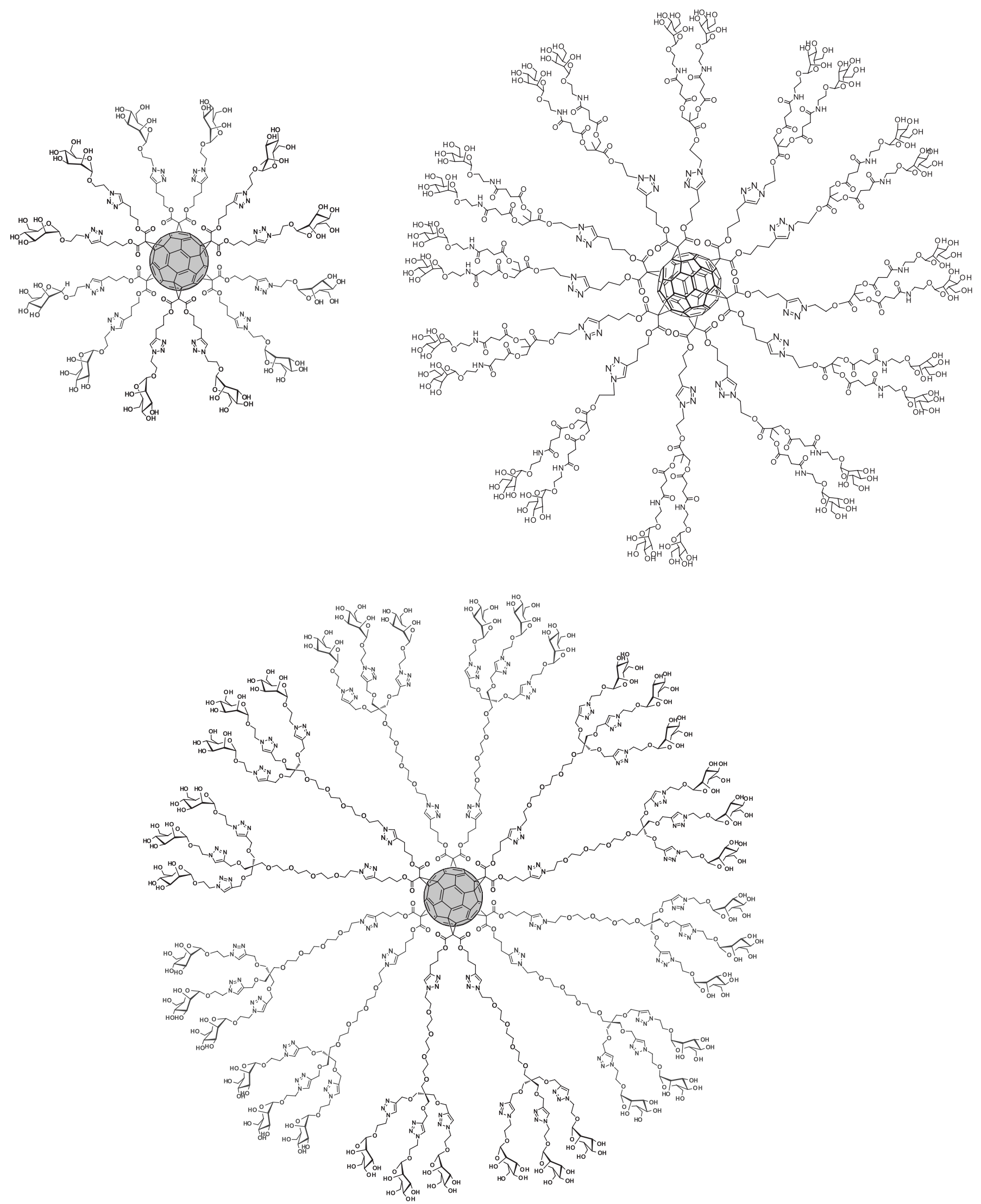

FIGURE 9 - Glycofullerenes with 12, 24 and 36 mannoses. 


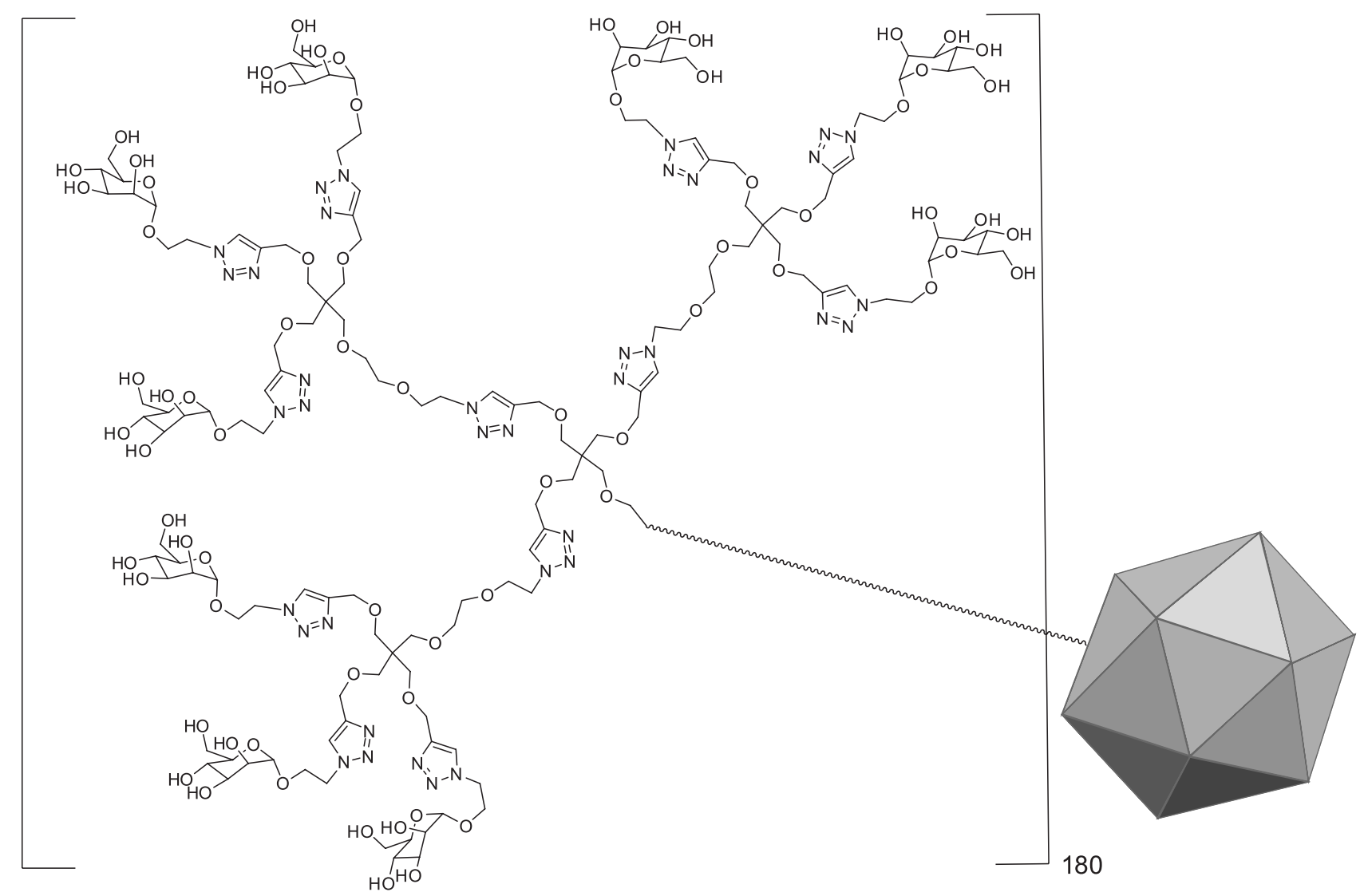

FIGURE 10 - Q $\beta$ particle bearing 1620 mannose units.

\section{Virus-like glycodendrinanoparticles}

Despite their elegant design, none of the artificial carbohydrates multivalent systems described (including the glycodendrofullerenes) have achieved the size and the valency to mimic properly natural systems implicated in DC-SIGN dependent infection processes such as viruses or other pathogens while maintaining full control of shape and structure. In the particular cases of glycodendritic structures, valency up to 100 are very rare and, in most of the cases, without full control of shape. Recently, a novel strategy of "nested polyvalency" was reported to achieve a controlled design of highly polyvalent glycodendriproteins. This approach was performed through the multivalent assembly of protein monomers themselves carrying polyvalent glycan display motifs (glycodendrons) (Ribeiro-Viana et al., 2012a). These synthetic protein assemblies display the highest known number of glycans $(n=1620)$ yet presented in a homogeneous manner (Figure 10). To perform the construction of glycodendriprotein nanoparticles trying to mimic the display in target pathogens, the self-assembled protein sphere-like icosahedron Q $\beta$ (Kozlovska et al., 1993) was used. The monomer of this protein can assemble into a 180 copy multimer. Using a tag-and modify strategy
(Chalker, Bernardes, Davis, 2011), a non-natural alkyne containing amino acid (tag), the L-homopropargyl glycine (Hpg), was introduced in the Q $\beta$ monomer. This tag was used for the attachment of glycodendrons with three and nine mannose units appropriately functionalized at the focal position with and azide group. The well-defined polyvalent glycoprotein assemblies presenting on their surface 1620 copies of mannose was tested in the DC-SIGN dependent Ebola pseudotype infection model.

The glycoprotein particles showed exciting antiviral activity, preventing dendritic cells infection by Ebola pseudotyped virus through competitive blockage of the DC-SIGN receptor in the nanomolar to picomolar range (Ribeiro-Viana et al., 2012a). This result clearly indicates the efficiency of these systems to interact with this pattern recognition receptor and to compete with pathogens during their entry into target cells.

\section{CONCLUSIONS}

The field of dendrimers is in its maturity and many achievements and goals have been reached since the first publication describing the synthesis of a dendritic molecule in 1978 (Buhleier, Wehner, Vögtle, 1978). One of the most 
interesting areas of research where dendrimers start to have an important contribution is nanomedicine. Taking advantage of the possibilities that offer the dendritic structures and the opportunities to combine biomolecules or any kind of ligands with these platforms for a multivalent presentation, many different applications have been described for these so beautiful and interesting molecules. The combination of carbohydrates with dendrimers allows the creation of glycodendrimers, very powerful tools to be exploited in the field of glycoscience mimicking the presentation of carbohydrates in nature. DC-SIGN, a very important and attractive receptor with relevant biological implications, has been one of the targets for these glycodendrimers. Several examples have been described in the literature that demonstrate the potential applications of glycodendritic structures to interact efficiently with DC-SIGN inhibiting infection processes mediated by this lectin. From these examples, important lessons came out respect to the necessary relevant issues to have access to effective glycodendritic molecules. Efficient chemistries, valency, size, spatial presentation, flexibility and accessibility of the ligands are among the important issues to be considered. Still, much work remains be done in the near future and novel scaffolds for multivalent presentations will be explored to achieve new goals and applications.

\section{ACKNOWLEGEDMENTS}

We would like to thanks the financial support by MINECO of Spain CTQ2011-23410 and the EU RTN CARMUSYS (PITN-GA-2008-213592). J.J thanks CSIC for a JAE-DOC contract.

\section{REFERENCES}

ARCE, E.; NIETO, P.M.; DIAZ, V.; CASTRO, R.G.; BERNAD, A.; ROJO, J. Glycodendritic structures based on boltorn hyperbranched polymers and their interactions with Lens culinaris lectin. Bioconjugate Chem., v.14, p.817-823, 2003.

BERNARDI, A.; JIMENEZ-BARBERO, J.; CASNATI, A.; DE CASTRO, C.; DARBRE, T.; FIESCHI, F.; FINNE, J.; FUNKEN, H.; JAEGER, K.-E.; LAHMANN, M.; LINDHORST, T.K.; MARRADI, M.; MESSNER, P.; MOLINARO, A.; MURPHY, P.V.; NATIVI, C.; OSCARSON, S.; PENADES, S.; PERI, F.; PIETERS, R.L.; RENAUDET, O.; REYMOND, J.-L.; RICHICHI, B.; ROJO, J.; SANSONE, F.; SCHÄFFER, C.; TURNBULL, W.B.; VELASCO-TORRIJOS, T.; VIDAL, S.; VICENT, S.; WENNEKES, T.; ZUILHOF, H.; IMBERTY, A. Multivalent glycoconjugates as anti-pathogenic agents. Chem. Soc. Rev., v.42, p.4709-4727, 2013.
BERTOZZI, C.R.; KIESSLING, L.L. Chemical glycobiology. Science, v.291, p.2357-2364, 2001.

BERZI, A.; REINA, J.J.; OTTRIA, R.; SUTKEVICIUTE, I.; ANTONAZZO, P.; SANCHEZ-NAVARRO, M.; CHABROL, E.; BIASIN, M.; TRABATTONI, D.; CETIN, I.; ROJO, J.; FIESCHI, F. BERNARDI, A.; CLERICI, M. A glycomimetic compound inhibits DC-SIGN-mediated HIV infection in cellular and cervical explant models. AIDS, v.26, p.127-137, 2012.

BEZOUŠKA, K. Design, functional evaluation and biomedical applications of carbohydrate dendrimers (glycodendrimers). J. Biotechnol., v.90, p.269-290, 2002.

BIELAWSKI, C.W.; GRUBBS, R.H. Living ring-opening metathesis polymerization. Prog. Polym. Sci., v.32, p.1$29,2007$.

BUHLEIER, E.; WEHNER, W.; VÖGTLE, F. "Cascade”and "Nonskid-Chain-like" syntheses of molecular cavity topologies". Synthesis, v.2, p.155-158, 1978.

CARDULLO, F.; DIEDERICH, F.; ECHEGOYEN, L.; HABICHER, T.; JAYARAMAN, N.; LEBLANC, R.M.; STODDART, J.F.; WANG, S. Stable langmuir and langmuir-blodgett films of fullerene-glycodendron conjugates. Langmuir, v.14, p.1955-1959, 1998.

CHABRE, Y.M.; ROY, R. Recent trends in glycodendrimer syntheses and applications. Curr. Top. Med. Chem., v.8, p.1237-1285, 2008.

CHABRE, Y.M.; ROY, R. Design and creativity in synthesis of multivalent neoglycoconjugates. Adv. Carbohydr. Chem. Biochem., v.63, p.165-393, 2010.

CHALKER, J.M.; BERNARDES, G.J.L.; DAVIS, B.G. A "tag-and-modify" approach to site-selective protein modification. Acc. Chem. Res., v.44, p.730-741, 2011.

CULF, A.S.; CUPERLOVIC-CULF, M.; OUELLETTE, R.J. Carbohydrate microarrays: survey of fabrication techniques. OMICS, v.10, p.289-310, 2006.

DAVIS, B.G. Synthesis of glycoproteins. Chem. Rev., v.102, p.579-602, 2002.

EISSA, A.M.; CAMERON, N.R. Glycopolymers conjugates. Adv. Polym. Sci., v.253, p.71-114, 2013. 
EL-BOUBBOU, K.; AND HUANG, X. Glyco-Nanomaterials: translating insights from the "Sugar-Code" to biomedical applications. Curr. Med. Chem., v.18, p.2060-2078, 2011.

ENES, R.F.; TOMÉ, A.C.; CAVALEIRO, J.A.S.; EL-AGAMEY, A.; McGARVEY, D.J. Synthesis and solvent dependence of the photophysical properties of [60]fullerene-sugar conjugates. Tetrahedron, v.61, p.11873-11881, 2005.

FEINBERG, H.; MITCHELL, D.A.; DRICKAMER, K.; WEIS, W.I. Structural basis for selective recognition of oligosaccharides by DC-SIGN and DC-SIGNR. Science, v.294, p.2163-2166, 2001.

FEINBERG, H.; GUO, Y.; MITCHELL, D.A.; DRICKAMER, K.; WEIS, W.I. Extended neck regions stabilize tetramers of the receptors DC-SIGN and DC-SIGNR. J. Biol. Chem., v.280, p.1327-1335, 2005.

FEINBERG, H.; CASTELLI, R.; DRICKAMER, K.; SEEBERGER, P.H.; WEIS, W.I. Multiple modes of binding enhance the affinity of DC-SIGN for high mannose $N$-linked glycans found on viral glycoproteins. J. Biol. Chem., v.282, p.4202-4209, 2007.

FERNANDEZ-MEGIA, E.; CORREA, J.; RODRÍGUEZMEIZOSO, I.; RIGUERA, R. A click approach to unprotected glycodendrimers. Macromolecules, v.39, p.2113-2120, 2006.

FRANC, G.; KAKKAR, A.K. "Click” methodologies; efficient, simple and greener routes to design dendrimers. Chem. Soc. Rev., v.39, p.1536-1544, 2010.

FRÉCHET, L.M.J.; TOMALIA, D.A. Dendrimers and other dendritic polymers. Chichester: Wiley, 2001. 633 p.

FULTON, D.A.; STODDART, J.F. Neoglycoconjugates based on cyclodextrins and calixarenes. Bioconjugate Chem., v.12, p.655-672, 2001.

GABIUS, H.-J.; ANDRÉ, S.; JIMÉNEZ-BARBERO, J.; ROMERO, A.; SOLÍS, D. From lectin structure to functional glycomics: principles of the sugar code. Trends Biochem. Sci., v.36, p.298-313, 2011.

GALAN, M.C.; DUMY, P.; RENAUDET. O. Multivalent glycol(cyclo)peptides. Chem. Soc. Rev., v.42, p.4599-4612, 2013.
GARBER, K.C.A.; WANGKANONT, K.; CARLSON, E.E.; KIESSLING, L.L. A general glycomimetic strategy yields non-carbohydrate inhibitors of DC-SIGN. J. Chem. Soc. Chem. Commun., v.46, p.6747-6749, 2010.

GEIJTENBEEK, T.B.H.; TORENSMA, R.; VAN VLIET, S.J.; VAN DUIJNHOVEN, G.C.F.; ADEMA, G.J.; VAN KOOYK, Y.; FIGDOR, C.G. Identification of DC-SIGN, a novel dendritic cell-specific ICAM-3 receptor that supports primary immune responses. Cell, v.100, p.575-585, 2000.

GEIJTENBEEK, T.B.H.; KWON, D.S.; TORENSMA, R.; VAN VLIET, S.J.; VAN DUIJNHOVEN, G.C.F.; MIDDEL, J.; CORNELISSEN, I.L.M.H.A.; NOTTET, H.S.L.M.; KEWAL RAMANI, V.N.; LITTMAN, D.R.; FIGDOR, C.G.; VAN KOOYK, Y. DC-SIGN, a dendritic cell-specific HIV-1-binding protein that enhances trans-infection of T cells. Cell, v.100, p.587-597, 2000a.

GHAZARIAN, H.; IDONI, B.; OPPENHEIMER, S.B. A glycobiology review: carbohydrates, lectins and implications in cancer therapeutics. Acta Histochem., v.113, p.236-247, 2011.

GOMEZ-GARCÍA, M.; BENITO, J.M.; BUTERA, A.P.; ORTIZ MELLET, C.; GARCÍA FERNANDEZ, J.M.; JIMENEZ BLANCO, J.L. Synthesis of heteroglycoclusters by using orthogonal chemoselective ligations. J. Org. Chem., v.77, p.1273-1288, 2012.

GUO, Y.; FEINBERG, H.; CONROY, E.; MITCHELL, D.A.; ALVAREZ, R.; BLIXT, O.; TAYLOR, M.E.; WEIS, W.I.; DRICKAMER, K. Structural basis for distinct ligandbinding and targeting properties of the receptors DC-SIGN and DC-SIGNR. Nat. Struct. Mol. Biol., v.11, p.591-598, 2004.

GUPTA, G.; SUROLIA, A. Glycomics: an overview of the complex glycocode. Adv. Exp. Med. Biol., v.749, p.1-13, 2012.

HIJAZI, K.; MARRADI, M.; CLAVEL, C.; CAMPION, C.; KELLY, C.; PENADES, P. Gold mano-glyconanoparticles: multivalent systems to block HIV-1 gp120 binding to the lectin DC-SIGN. Chem. Eur. J., v.15, p.9874-9888, 2009.

ISOBE, H.; CHO, K.; SOLIN, N.; WERZ, D.B.; SEEBERGER, P.H.; NAKAMURA, E. Synthesis of fullerene glycoconjugates via a copper-catalyzed Huisgen cycloaddition reaction. Org. Lett., v.9, p.4611-4614, 2007. 
ITO, H.; TADA, T.; SUDO, M.; ISHIDA, Y.; HINO, T.; SAIGO, K. [60]fullerenoacetyl chloride as a versatile precursor for fullerene derivatives: efficient ester formation with various alcohols. Org. Lett., v.5, p.2643-2645, 2003.

JORALEMON, M.J.; O'REILLY, R.K.; MATSON, J.B.; NUGENT, A.K.; HAWKER, C.J.; WOOLEY, K.L. Dendrimers clicked together divergently. Macromolecules, v.38, p.5436-5443, 2005.

KAMERLING, J.P. Comprehesive glycoscience: from chemistry to system biology. Amsterdam: Elsevier, 2007. v.3-4.

KATO, H.; KANETA, N.; NII, S.; KOBAYASHI, K.; FUKUI, N.; SHINOHARA, H.; NISHIDA, Y. Preparation and supramolecular properties of unadulterated glycosyl liposomes from a $\operatorname{Bis}(\alpha$-D-mannopyranosyl)-[60] fullerene conjugate. Chem. Biodivers., v.2, p.1232-1241, 2005.

KILPATRICK, D.C. Hanbook of animal lectins: properties and biomedical applications. Chichester: John Wiley \& Sons, 2000. $468 \mathrm{p}$.

KOLB, H.C.; FINN, M.G.; SHARPLES, K.B. Click chemistry: diverse chemical function from a few good reactions. Angew. Chem. Int. Ed., v.40, p.2004-2021, 2001.

KOZLOVSKA, T.M.; CIELENS, I.; DREILINNA, D.; DISLERS, A.; BAUMANIS, V.; OSE, V.; PUMPENS, P. Recombinan RNA phage Qbb capsid particles synthesized and self-assembled in Escherichia coli. Gene, v.137, p.133137, 1993.

LASALA, F.; ARCE, E.; OTERO, J.R.; ROJO, J.; DELGADO, R. Mannosyl glycodendritic structure inhibits DC-SIGNMediated ebola virus infection in cis and trans. Antimicrob. Agents Chemother., v.47, p.3970-3972, 2003.

LEE, Y.C.; LEE, R.T. Carbohydrate-protein interactions: basis of glycobiology. Acc. Chem. Res., v.28, p.321-327, 1995.

LI, Y.; CHENG, Y.; XU, T. Design, synthesis and potent pharmaceutical applications of glycodendrimers: a mini review. Curr. Drug Discov. Technol., v.4, p.246-254, 2007.

LUCZKOWIAK, J.; SATTIN, S.; SITKEVICIUTE, I.; REINA, J.J.; SÁNCHEZ-NAVARRO, M.; THÉPAUT, M.; MARTÍNEZ-PRATS, L.; DAGHETTI, A.; FIESCHI, F.; DELGADO, R.; BERNARDI, A.; ROJO, J. Pseudosaccharide functionalized dendrimers as potent inhibitors of DC-SIGN dependent Ebola pseudotyped viral infection. Bioconjugate Chem., p.22, p.1354-1365, 2011.
LUCZKOWIAK, J.; MUÑOZ, A.; SÁNCHEZ-NAVARRO, M.; RIBEIRO-VIANA, R.; GINIEIS, A.; ILLESCAS, B.M.; MARTÍN, N.; DELGADO, R.; ROJO, J. Glycofullerenes inhibit viral infection. Biomacromolecules, v.14, p.431437, 2013.

MALKOCH, M.; SCHLEICHER, K.; DROCKENMULLER, E.; HAWKER, C.J.; RUSSELL, T.P.; WU, P.; FOKIN, V.V. Structurally diverse dendritic libraries: a highly efficient functionalization approach using click chemistry. Macromolecules, v.38, p.3663-3678, 2005.

MAMMEN, M.; CHOI, S.-K.; WHITESIDES, G.M. Polyvalent interactions in biological systems: implications for design and use of multivalent ligands and inhibitors. Angew. Chem. Int. Ed., v.37, p.2755-2794, 1998.

MARI, S.; SANCHEZ-MEDINA, I.; MEREGHETTI, P.; BELVISI, L.; JIMÉNEZ-BARBERO, J.; BERNARDI, A. Synthesis and conformational analysis of an $\alpha-D-$ mannopyranosyl-(1,2)- $\alpha$-D-mannopyranosyl-(1,6)- $\alpha$-Dmannopyranose mimic. Carbohydr. Res., v.342, p.1859$1868,2007$.

MARRADI, M.; CHIODO, F.; GARCÍA, I.; PENADÉS, S. Glyconanoparticles as multifunctional and multimodal carbohydrate systems. Chem. Soc. Rev., v.42, p.4515-4517, 2013.

MARTÍNEZ,A.; ORTIZ MELLET, C.; GARCÍAFERNÁNDEZ, J.M. Cyclodextrin-based multivalent glycodisplays: covalent and supramolecular conjugates to access carbohydrate-protein interactions. Chem. Soc. Rev., v.42, p.4746-4773, 2013.

MARTINEZ-AVILA, O.; BEDOYA, L.M.; MARRADI, M.; CLAVEL, C.; ALCAMI, J.; PENADES, P. Multivalent mano-glyconanoparticles inhiblit DC-SIGN-mediated HIV-1 trans-infection of human T cells. ChemBioChem, v.10, p.1806-1809, 2009.

MITCHELL, D.A.; FADDEN, A.J.; DRICKAMER, K. A novel mechanism of carbohydrate recognition by the C-type lectins DC-SIGN and DC-SIGNR: subunit organization and binding to multivalent ligands. J. Biol. Chem., v.276, p.28939-28945, 2001.

MIURA, Y. Design and synthesis of well-defined glycopolymers for the control of biological functionalities. Polymer J., v.44, p.679-689, 2012. 
NEWKOME, G.R.; MOOREFIELD, C.N.; VÖGTLE, F. Dendrimers and dendrons: concepts, syntheses, applications. Weinheim: Wiley VCH, 2001. 635 p.

NIERENGARTEN, J.-F.; IEHL, J.; MOLLER, M.; GOYARD, D.; ILLESCAS, B.M.; MUÑOZ, A.; MARTÍN, N.; ROJO, J.; SÁNCHEZ-NAVARRO, M.; CECIONI, S.; VIDAL, S.; BUFFET, K.; DURKA, M.; VINCENT, S.P. Fullerene sugar balls. J. Chem. Soc. Chem. Commun., v.46, p.38603862, 2010.

NISHIDA, Y.; MIZUNO, A.; KATO, H.; YASHIRO, T.; OHTAKE, T.; KOBAYASHI, K. Stereo- and Biochemical Profiles of the 5-6- and 6-6-Junction Isomers of $\alpha$-DMannopyranosyl [60]Fullerenes. Chem. Biodiversity, v.1, p.1452-1464, 2004.

PAYNE, R.J.; WONG, C.H. Advances in chemical ligation strategies for the synthesis of glycopeptides and glycoproteins. J. Chem. Soc. Chem. Commun., v.46, p.2143, 2010.

REINA, J.J.; SATTIN, S.; INVERNIZZI, D.; MARI, S.; MARTINEZ-PRATS, L.; TABARANI, G.; FIESCHI, F.; DELGADO, R.; NIETO, P.M.; ROJO, J.; BERNARDI, A. 1,2-Mannobioside mimic: synthesis, DC-SIGN interaction by NMR and docking, and antiviral activity, ChemMedChem, v.2, p.1030-1036, 2007.

REINA, J.J.; BERNARDI, A.; CLERICI, M.; ROJO, J. HIV microbicides: state of the art and new perspectives on the development of entry inhibitors. Future Med. Chem., v.2, p.1141-1159, 2010.

REINA, J.J.; BERNARDI, A. Carbohydrates mimics and lectins: a source of new drugs and therapeutic opportunities. Mini Rev. Med. Chem., v.12, p.1434-1442, 2012.

RIBEIRO-VIANA, R.; GARCÍA-VALLEJO, J.J.; COLLADO, D.; PEREZ-INESTROSA, E.; BLOEM, K.; VAN KOOYK, Y.; ROJO, J. BODIPY-labeled DC-SIGN-targeting glycodendrons efficiently internalize and route to lysosomes in human dendritic cells. Biomacromolecules, v.13, p.3209$3219,2012$.

RIBEIRO-VIANA, R.; SÁNCHEZ-NAVARRO, M.; LUCZKOWIAK, J.; KOEPPE, J.R.; DELGADO, R.; ROJO, J.; DAVIS, B.G. Virus-like glycodendrinanoparticles displaying quasi-equivalent nested polyvalency upon glycoprotein platforms potently block viral infection. Nat. Commun., v.3, 2012a. Doi: 10.1038/ncomms2302.
ROJO, J.; DELGADO, R. Glycodendritic structures: promising new antiviral drugs. J. Antimicrob. Chemother., v.54, p.579$581,2004$.

ROSTOVTSEV, V.V.; GREEN, L.G.; FOKIN, V.V.; SHARPLES, K.B. A stepwise huisgen cycloaddition process: copper(I)catalyzed regioselective "ligation" of azides and terminal alkynes. Angew. Chem. Int. Ed., v.41, p.2596-2599, 2002.

ROY, R. Synthesis and some applications of chemically defined multivalent glycoconjugates. Curr. Opin. Struct. Biol., v.6, p.692-702, 1996.

ROY, R.; BAEK, M.-G. Glycodendrimers: novel glycotope isosteres unmasking sugar coding. Case study with T-antigen markers from breast cancer MUC1 glycoprotein. J. Biotechnol., v.90, p.291-309, 2002.

ROY, R. A decade of glycodendrimer chemistry. Trends Glycosci. Glyc., v.15, p.289-308, 2003.

SÁNCHEZ-NAVARRO, M.; ROJO J. Targeting DC-SIGN with carbohydrate multivalent systems. Drugs News Perspect., v.23, p.557-572, 2010.

SÁNCHEZ-NAVARRO, M.; MUÑOZ, A.; ILLESCAS, B.M.; ROJO, J.; MARTIN, N. [60]Fullerene as multivalent scaffold efficient molecular recognition of globular glycofullerenes by concanavalin. Chem. Eur. J., v.17, p.766-769, 2011.

SÁNCHEZ-NAVARRO, M.; ROJO J. Synthetic strategies to create dendrimers: advantages and drawbacks. In: FUENTE, J.M.; GRAZU, V. Nanobiotechnology: inorganic nanoparticles vs organic nanoparticles. Oxford: Frontiers in Nanoscience, 2012. v.4, chap.5, p.137-149.

SATTIN, S.; DAGHETTI, A.; THÉPAUT, M.; BERZI, A.; SÁNCHEZ-NAVARRO, M.; TABARANI, G.; ROJO, J.; FIESCHI, F.; CLERICI, M.; BERNARDI, A. Inhibition of DC-SIGN-mediated HIV infection by a linear trimannoside mimic in a tetravalent presentation. ACS Chem. Biol., v.3, p.301-312, 2010.

SERRANO-SIERRA-GOMEZ, D.; SIERRA-FILARDI, E.; MARTINEZ-NUÑEZ, E.T.; CAPARROS, E.; DELGADO, R.; MUÑOZ-FERNANDEZ, A.; ABAD, M.A.; JIMÉNEZBARBERO, J.; LEAL, M.; CORBI, A.L. Structural requirements for multimerization of the pathogen receptor dendritic cell-specific ICAM3-grabbing non-integrin (CD209) on the cell surface. J. Biol. Chem., v.283, p.3889-3903, 2008. 
SHARON, N.; LIS, H. History of lectins: from hemagglutinins to biological recognition molecules. Glycobiology, v.14, p.53R-62R, 2004.

SCHUSTER, M.C.; MANN, D.A.; BUCHHOLZ, T.J.; JOHNSON, K.M.; THOMAS, W.D.; KIESSLING, L.L. Parallel synthesis of glycomimetic libraries: targeting a C-type lectin. Org. Lett., v.5, p.1407-1410, 2003.

TABARANI, G.; REINA, J.J.; EBEL, C.; VIVES, C.; LORTAT-JACOB, H.; ROJO, J.; FIESCHI, F. Mannose hyperbranched dendritic polymer interact with clustered organization of DC-SIGN and inhibit gp120 binding. FEBS Lett., v.580, p.2402-2408, 2006.

TABARANI, G.; THEPAUT, M.; STROEBEL, D.; EBEL, C.; VIVES, P.; VACHETTE, P.; DURAMD, D.; FIESCHI, F. DC-SIGN neck domain is a $\mathrm{pH}$-sensor controlling oligomerization. J. Biol. Chem., v.284, p.21229-21240, 2009.

TORNØE, C.W.; CHRISTENSEN, C.; MEDAL, M. Peptidotriazoles on solid phase: [1,2,3]-Triazoles by regiospecific copper(I)-catalyzed 1,3-Dipolar cycloadditions of terminal alkynes to azides. J. Org. Chem., v.67, p.30573064, 2002.

TURNBULL, J.E.; STODDART, J.F. Design and synthesis of glycodendrimers. J. Biotechnol., v.90, p.231-255, 2002.

TURNBULL, J.E.; FIELD, R.A. Emerging glycomics technologies. Nat. Chem. Biol., v.3, p.74-77. 2007.

VAN KOOYK, Y.; GEIJTENBEEK, T.B. DC-SIGN: escape mechanism for pathogens. Nat. Rev. Immunol., v.3, p.697709, 2003.

VARKI, A. Biological roles of oligosaccharides: all of the theories are correct. Glycobiology, v.2, p.97-130, 1993.
VARKI, A.; CUMMINGS, R.; ESKO, J.; FREEZE, H.; HART, G.; MARTH, J. Essentials of glycobiology. 2.ed. New York: Cold Spring Harbor Laboratory Press, 1999. 653 p.

VON DER LIETH, C.-W.; FRANK, M.; LINDHORST, T.K. Molecular dynamics simulations of glycoclusters and glycodendrimers. J. Biotechnol., v.90, p.311-337, 2002.

WANG, S.K.; LIANG, P.H.; ASTRONOMO, R.D.; HSU, T.L.; HSIEH, S.L.; BURTON, D.R.; WONG, C.H. Targeting the carbohydrates on HIV-1: interaction of oigomannose dendrons with human monoclonal antibody $2 \mathrm{G} 12$ and DCSIGN. P. Natl. Acad. Sci. USA, v.105, p.3690-3695, 2008.

WEISS, I.W.; DRICKAMER, K. Structural basis of the lectincarbohydrate recognition. Annu. Rev. Biochem., v.65, p.441-473, 1996.

WEIS, I.W.; TAYLOR, M.E.; DRICKAMER, K. The C-type lectin superfamily in the immune system. Immunol. Rev., v.163, p.19-34, 1998.

WERZ, D.B.; SEEBERGER P.H. Chemical glycomical glycomics as basis for drug discovery. In: SCHREIBER, S.L.; KAPOOR, T.M.; WESS, G. (Eds.). Chemical biology: from small molecules to systems biology and drug design. Weinheim: Wiley-VCH, 2007. chap.11, p.668-691.

WESTERLIND, E. Synthetic glycopeptides and glycoproteins with applications in biological research. Beilstein J. Org. Chem., v.8, p.804-818, 2012.

WU, P.; FELDMAN, A.K.; NUGENT, A.K.; HAWKER, C.J.; SCHEEL, A.; VOIT, B.; PYUN, J.; FRÉCHET, J.M.J.; SHARPLESS, K.B.; FOKIN, V.V. Efficiency and fidelity in a click-chemistry route to triazole dendrimers by the copper(I)-catalyzed ligation of azides and alkynes. Angew. Chem. Int. Ed., v.43, p.3928-3932, 2004. 